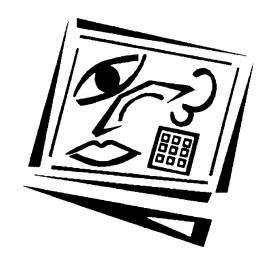

\title{
Challenging mobile learning discourse through research: Student perceptions of Blackboard Mobile Learn and iPads
}

\author{
Shelley Kinash, Jeffrey Brand and Trishita Mathew \\ Bond University
}

\begin{abstract}
Many university academics disagree with the rationale that we should pursue mobile learning because 21st century students are apparently demanding it. We argue that the only defensible rationale for making mobile learning part of pedagogy is because it enhances student learning. This presentation shares results from research with 135 students engaged in mobile learning over two semesters. It addresses the question of whether Blackboard Mobile Learn made a perceived difference to their learning. Results revealed that in-class, students used their mobile devices for Blackboard Mobile Learn to the same extent as they used them for searching the web for study, accessing university web pages, email and making Facebook posts, but less than they used them for browsing the web for pleasure and Facebook reading. The majority of students were neutral when asked if they prefer Mobile Learn over PC access to Blackboard. Students were likewise neutral when asked whether they perceived iPads to improve their learning. There was higher frequency agreement that using $i P a d s$ motivated them to learn. Qualitative feedback from focus groups was mixed, but largely positive. The overall interpretation was that it is a matter of course that students would access their subject site via mobile devices.
\end{abstract}

\section{Introduction}

Tablets have arrived. The first consumers received iPads with WiFi and 3G on 30 April 2010 in the USA (Pope \& Kerris, 2010). Portability, functional screen size, abundance of apps, multiple routes for Internet access, multimedia and other specifications unleash teaching and learning affordances for the classroom and beyond (Banister, 2010; Gupta \& Koo, 2010; Traxler, 2010). In the 18 months since the release of the iPad, uptake in Australia is flaring like the proverbial bushfire. By October 2010 (6 months post release), 250,000 Australians owned the iPad (Colley, 2010). However, for some academics and educational theorists, mobile learning in education is a contested space (Simonson, 2010; Traxler, 2007).

The prevalent definition of mobile learning in scholarly literature is the use of portable devices with Internet connection capability in education contexts. Wang, Wiesemes and Gibbons (2012) stated this definition simply as, "learning through mobile devices" (p. 570). These authors added three important qualifications to the definition, and this full operationalisation is consistent with the framework of the research described in this paper. First, the mobility component means that students are free to move within, beyond and between multiple environments and between topics and disciplinary contents and contexts. Second, use of the portable devices means that learning is not confined to formal educational contexts; learning is extended within informal 
opportunities such as home and work. Third, mobile learning is not a one-way exchange from lecturer to students, but constructing understanding within participating communities.

Many educators indicate positive perceptions about the potential for mobile learning (Caverly, Ward \& Caverly, 2009; Cobcroft, Towers, Smith \& Bruns, 2006; Cochrane \& Bateman, 2010; Cornelius \& Marston, 2009; Demirbilek, 2010; Dyson, Litchfield, Lawrence, Raban \& Leijdekkers, 2009; Guy, 2009; Kukulska-Hulme \& Traxler, 2005; Mahmoud, 2008; Wang, Shen, Novak \& Pan, 2009; Zawacki-Richter, Brown \& Delport, 2009). However, mobile learning is contested due to weak conceptualisation (ElHussein \& Cronje, 2010; Kurubacak, 2007; Park, 2011; Wali, Winters \& Oliver, 2008). Without a strong conceptualisation, discourse is likewise problematic. The operational definition of discourse is language plus power. In other words, the way in which we talk about a phenomenon such as mobile learning both describes and constructs the way in which it is put into practice (Foucault, 1972; Mills, 1997; Spradley, 1979).

The nearly universally presented rationale for mobile learning is that the current and incoming tech-savvy 21st century learners, many of whom, have "grown up digital" (Tapscott, 2009) expect it (Andone, Dron \& Pemberton, 2009; Annetta, 2008; Gupta \& Koo, 2010; Kim, Jain, Westhoff \& Rezabek, 2008; Monahan, 2007; Proserpio \& Gioia; 2007). Generational learner discourse has been critiqued (Kinash, 2011). Donnison (2009) summarised the criticisms as "populist approach, their propensity to describe a generation in universalising or essentialist terms and their tendency to make claims not founded on scholarship or rigorous research" (p. 337). Wang, Wiesemes and Gibbons (2012) interpreted their own research as indicating that dividing learners into digital natives and digital immigrants is not helpful. They wrote, "mature learners might be more critical of new technology, but it does not mean that they have different expectations and demands" (p. 575). Some academics argue that student whim is a questionable reason to interrupt pedagogy (Hardy, 2010). In the introduction to their article, Dyson et al. (2009) wrote a paragraph about the necessary alignment of teaching tools with the technologies used by current students. They opened their next paragraph with the statement, "however, much still needs to be done to demonstrate how to enhance student learning through the use of these technologies" (p. 251). Further, it is questionable whether the 21st century student is indeed demanding mobile learning. Kazlauskas and Robinson (2012) wrote, "the caricature of the 21st century student as an avid consumer of any and all technology does not necessarily transfer to the learning environment" (p. 328). Whereas overall the literature conveys a positive perspective on the educative potential of mobile learning, the predominant discourse of generational demand as rationale is troublesome.

This paper confronts the dominant discourse of 21st century student expectations with the challenging discourse of assurance of learning. This is in keeping with the collection of chapters assembled by Vavoula, Pachler and Kukulska-Hulme (2010) and other researchers such as Kearney, Schuck, Burden and Aubusson (2012), to move the focus of mobile learning research from technology to learning. The definition of assurance of learning is the collection of data and mapping of curriculum to provide evidence that students are receiving a quality education (Azeem et.al., 2009; Chalmers, 2008; Kinash et.al., in press; Martell, 2007a, 2007b). Assurance of learning is a complementary concept to scholarship of teaching and learning (Boyer, 1990; Huber \& Hutchings, 2005). For two decades, the higher education focus has moved from the concept of teaching to that of learning (Ramsden, 2003; Stiles, Jones \& Paradkar, 2011). 
Whereas university quality assurance used to focus specifically on the skills, capacities and best practice of teaching, a paradigm shift has put the focus on student learning. In basic terms, the shift has been from the input factor of teaching to the output factor of learning (Biggs \& Tang, 2007). Rather than, or in addition to, collecting data on teaching qualifications, universities and external organisations are now analysing student performance data, such as measures of whether students have hard and soft skills for successful career performance (Barrie, Ginns \& Prosser, 2005; Business Council of Australia, 2011). In short, the core question is what evidence do we have that the university experience is making an outstanding contribution to student learning?

In order to begin addressing the question of whether we should revise the term from mobile learning to mobile education and thereby interrupt the discourse that conveys an $a$ priori relationship between mobility and learning (Traxler, 2009), we situated our research at one of the manifestations of mobile device introduction. Wu et al., 2012, and Hung \& Zhan, 2012 conducted meta-analyses of mobile learning literature. Both analyses revealed that effectiveness is the most prevalent content classification of mobile learning research. Wu et al. added that the outcome of the majority of these studies was positive effectiveness. The research described in this paper can also be classified in the domain of mobile learning effectiveness within the context of pedagogy. One of the main distinctive contributions of this paper to the existing literature is research on student use of $i$ Pads for learning. Wu et al. (2012) wrote, "Mobile phones and PDAs are the most commonly used devices for mobile learning, but these may be replaced in the future by new emerging technologies" (p. 11). To date, there are very few published research studies that include use of $i P a d s$ and other similar tablets in learning contexts.

Our inquiry was into student use of the Blackboard learning management system app for mobile devices, called (in keeping with dominant promotional semantics) Blackboard Mobile Learn. Hanley (2011) classified Blackboard as a course management system (CMS) or learning managment system (LMS). Blackboard was chosen as the LMS in the research described in this paper because it is the leading LMS seller (Hanley, 2011). Hanley used his own research to operationally define the Blackboard LMS as used by universities, writing, "... most faculty use Blackboard or iLearn for publishing files, asynchronous communication like threaded discussion boards or forums, and online grade books" (p. 11). His analysis of teaching and learning and the perpetuated relationships between teachers and students led him to conclude "the CMS reproduces a very traditional pedagogy" (p. 11). Likewise, Blin and Munro (2008) conducted analysis of usage statistics of another LMS, Moodle, to conclude that academics used the system to "replicate the prevailing face-to-face weekly lecture/tutorial delivery structure" (p. 484). Hanley described the LMS as primarily an automated delivery system. There is an inherent power system in which the students have the least level of access, control and contribution to their own education. He lamented:

In this representation of teaching and learning, teachers broadcast content and manage tasks, students are reduced to passive recipients, and learning takes place in a mysterious black box constructed in the space between content delivery and consumption. (p. 11)

Hanley is not the only sceptic of computer-assisted education, or at least of the current state of implementation (e.g. Laurillard, 2007; Spector, 2001). 
The studied condition presented in this paper was student use of Blackboard Mobile Learn. Blackboard Mobile Learn is an app that works on mobile devices such as the iPad, $i$ Pod and the iPhone and other smart phones. Once activated by the university, Blackboard Mobile Learn enables students to use their existing Blackboard username and password to access their subject sites, post to discussion forums, submit assignments and participate in all other activated information and communication tools using their mobile devices.

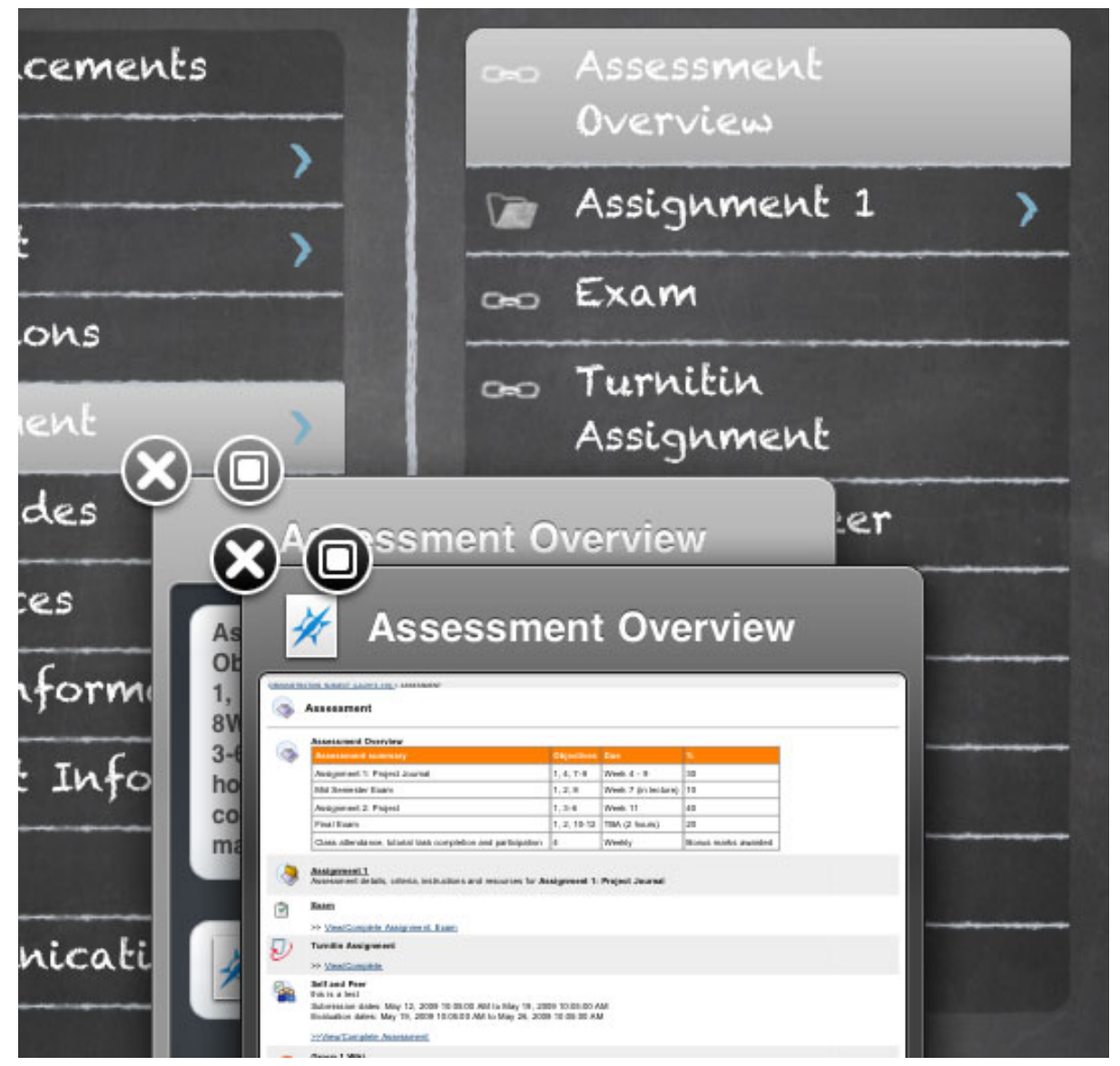

Figure 1: Screenshot of Blackboard Mobile Learn on an iPad

As a tool of mobile learning, Blackboard Mobile Learn has the forecasted potential to revolutionise education. Gupta and Koo (2010) wrote, "m-learning can be used as an effective tool to support classroom material, introduce new ways of learning, and help enhance study skills" (p. 76). The question is whether the promises hold up when students participate in mobile learning. Hanley (2011) wrote, "There is something counter-intuitive but familiar about this approach to technology: new technologies often heralded and sold as 'revolutionary', are deployed to do the same old things" (p. 11). Is this the case with Blackboard Mobile Learn? This was the key question addressed by the research described in this paper. We set out to discover to what extent students actually used Blackboard Mobile Learn when afforded the opportunity in their university 
studies. Our research questions were - what are undergraduate students' reported experiences and perceptions of Blackboard Mobile Learn, and mobile learning more generally?

\section{Method}

This project was framed as design-based research (DBR) (Middleton, Gorard, Taylor \& Bannan-Ritland, 2008; Wang \& Hannafin, 2005). DBR is a method geared towards bridging educational theory and practice, with the aim of understanding how students learn within their natural settings (school or university). One of the main advantages of this method is that research and learning have a symbiotic relationship, as research can be enhanced through the study of scholarship, which in turn can enrich and refine the learning process (Middleton et al., 2008). In order to answer the defined research questions regarding the students' actual experiences and their perceptions of those experiences, it was important that the research conditions did not interfere with the integrity of their phenomenology as undergraduate university students.

The primary reason DBR was selected as research methodology was that there is no manipulation of experimental conditions. The students, as volunteer research participants, spent no more time than normally spent engaged in class activities, and the conditions of the study were naturalistic, or what one would ordinarily expect in a university classroom facilitated by this particular educator. The only difference was that a loan scheme ensured that all students had use of iPads loaded with Blackboard Mobile Learn and an electronic version of the assigned textbook. Students were allowed and encouraged to use the loaned iPads, their own mobile devices, or both. While the majority of research questions addressed students' use of the loaned iPads (pre-loaded with Blackboard Mobile Learn), some of the questions probed use of mobile devices more generally. Schepman, Rodway, Beattie and Lambert (2012) described this multiplatform feature as a necessary condition of mobile learning research. They wrote that it is "... desirable to use technology which enables mobile learning on hardware that the students already own ... and which utilises relatively generic software which can be tailored to different learning tasks" (p. 308). Also in keeping with the DBR method, student use of mobile devices must be consistent with regular timeframes and locations. Use of mobile devices spans formal and informal settings (Sharples, 2009). In other words, it is not normative for students to only use mobile devices while at university and only for the applications defined by the educator. In order to be true to the methodology of this study, students had free reign with the mobile devices during the loan period. They were free to take them home and to load whatever applications they wished during the loan period.

A total of 135 students enrolled in an undergraduate subject titled Digital Media and Society in the final semester of 2010 and the first semester of 2011. The pedagogical design of this subject was such that the educator used a combination of face to face teaching methods such as lecture and discussion, and online methods such as immediate Internet search and online formative assessment. The students were invited to use their own mobile devices such as laptops, smart phones and tablets to participate in the digital components. To ensure that every student had access to mobile technologies, each student was also assigned to a loan schedule whereby an iPad was made available for university and home use for two-week periods. 
The studied subject and educator were intentionally selected as exemplars of higher education teaching and learning so that pedagogical design would not be a confounding research variable. In other words, the situated case allowed researchers to ask, when the pedagogical design and embedded use of Blackboard Mobile Learn in university teaching are optimised, will students use it and report satisfaction in using it? Evidence from student evaluation of teaching surveys and from peer observation of teaching pro-formas indicate that the educator in question has a developed philosophy of teaching, engages the students in active learning and provokes thinking through approaches such as Socratic questioning. The educator in question was the Head of School of Communication and Media. He was brought to the University in order to design and develop a program in emerging technologies and he started a multimedia, active learning lab for the students. In student evaluation of teaching surveys conducted over 3 years (2007-2009), 14 subjects, and 432 students, he achieved a mean score of $6.4 / 7$ in response to the question, "All things considered, how would you rate the effectiveness of this teacher in this subject." In summary, the introduction of mobile devices into this particular classroom was a natural and normative pedagogy.

As the key data collection instruments of the DBR process, all students completed questionnaires (Appendix) and students volunteered to participate in focus groups conducted during regularly scheduled tutorial times. A subset of questionnaire data, relevant to the research questions presented above, was analysed using SPSS version 18, a quantitative data analysis software [http://www-01.ibm.com/software/au/ana lytics/spss/]. The focus group data was analysed using NVivo version 8 , a qualitative data analysis software [http:/ / www.qsinternational.com/products_nvivo.aspx].

The focus groups were designed to enable interpretive inquiry using a phenomenological hermeneutic framework (Alvesson \& Sköldberg, 2000; van Manen, 1997). Phenomenology means the actual lived experience of the participants. Hermeneutics is named for the Greek Hermes who was the mythical messenger for the gods, translating meaning so that mortals could understand. Combined with phenomenological experience, hermeneutics enables participants to describe experiences, and researchers to interpret meanings of those experiences. Students were asked to comment on and discuss their experiences. This allowed the respondents to reflect on their actual experiences and co-created meanings through shared discussion, as opposed to forced choices or being influenced by the theoretical propositions of the researchers. Researchers writing about DBR have emphasised that interaction among students, such as that through the focus group process, is instrumental to the formation of subjective interpretation. The synergy and collaborative nature of group discussion is a key catalyst in the creation of an ongoing, cumulative discourse (Rasmussen \& Stephan, 2008). With respect to learning, it is revealing to ask students to describe their experiences and perceptions of the use of Blackboard Mobile Learn and observe whether learning emerged as a volunteered topic, in addition to directly asking students through the questionnaire whether they learned.

There were eight focus groups in total. Each had ten participants. The ten participants were those who had just returned iPads from the loan scheme. Each focus group was one-hour long. Set general themes were pursued in each focus group. Additional subthemes emerged. All discussions were audio recorded and transcribed for analysis. The portion of the focus group content that was extracted for this paper was students' described experience and perceptions of using Blackboard Mobile Learn, and mobile learning more generally. 


\section{Results}

\section{Participant demographics}

A total of 135 students (males $=49$, females $=86$ ) with ages ranging from 18 to 41 years $(M=21.97, S D=3.87)$ participated in the study. Participants were students enrolled in the subject Digital Media and Society in the final semester of 2010 and the first semester of 2011 at Bond University, Australia. Although all the participants stated that they were not technology resisters, $41 \%$ indicated that they were not technology users. Furthermore, $48 \%$ of the students stated that they were not technology savvy, even though a high percentage agreed that communication technologies have changed the world economy $(48 \%)$ and that communication technologies have changed the way people think $(40 \%)$. In addition, the majority (53\%) of the students reported that they used a computer of some kind all day, every day. The majority $(56 \%)$ of the students indicated that they were using an Internet-connected device on the day the questionnaire was administered. The device of choice for the majority $(37 \%)$ was a mobile phone, followed closely by a laptop (36\%). Regarding social networking sites, most of the students reported that they had a Facebook account $(75 \%)$, followed by a Twitter account $(34 \%)$, and finally by a Linkedin account (17\%). A large percentage $(68 \%)$ of students did not prefer e-books to print books and the majority of the participants $(61 \%)$ had not read any e-books over the past year, even though only $13 \%$ of the participants reported that they actively avoided e-books. The general reported use of technologies and self-classification provide the wider context with which to interpret specific results in regard to Blackboard Mobile Learn.

\section{Quantitative analysis of questionnaire data}

It should be noted that the quantitative analysis of questionnaire data represented in Figures 2 to 5 below are calculated on $n=90$ students. Whereas the demographic data from above is calculated on $n=135$, a full and complete data set was not available for 45 students in the data described below.

As the majority of the students in class were connected to some Internet-enabled device, they were asked to indicate the sites and applications they visited. The site with the highest reported visits (41\%) was Blackboard, followed by Facebook (36\%), Wikipedia $(20 \%)$ and finally by Twitter (18\%). The total percentage exceeds $100 \%$ because students reported visiting more than one particular site whilst in-class.

Specific to mobile learning, students were asked to indicate on a three-point Likerttype scale ranging from $1=$ not at all to $3=a$ lot their usage of the loaned iPads for Blackboard Mobile Learn, searching the web for study, the university web pages, student portal pages, taking notes in class, using email, listening to music, watching YouTube, surfing the web for pleasure, Facebook reading, Facebook posting, and installing applications. Student responses are summarised in Figure 2.

The activities with the highest self-reported frequencies (mean 2.5 - revealing moderate in-class usage) were surfing the web for pleasure and Facebook reading. Five activities closely followed with a score of 2.2. These activities were Blackboard Mobile Learn, searching the web for study, university web pages, using email and Facebook posts. The activities with the lowest use (1.4) were taking notes in class and listening to music. 


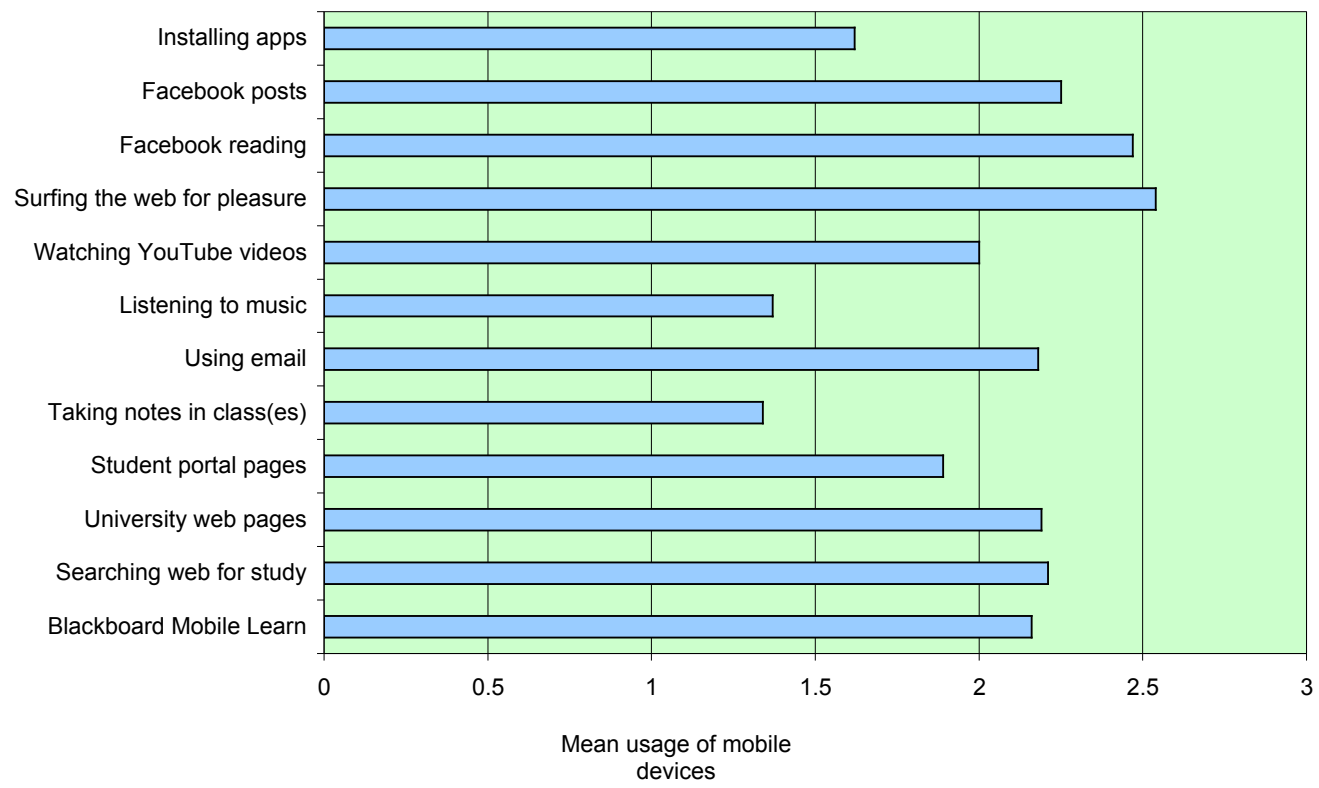

Figure 2: Mean reported usage of mobile device for various purposes

Students were asked to indicate on a five-point Likert type scale $(1=$ strongly disagree to $5=$ strongly agree) if they preferred Blackboard Mobile Learn over accessing Blackboard via the personal computer interface. As can be seen in Figure 3, most students neither agreed nor disagreed.

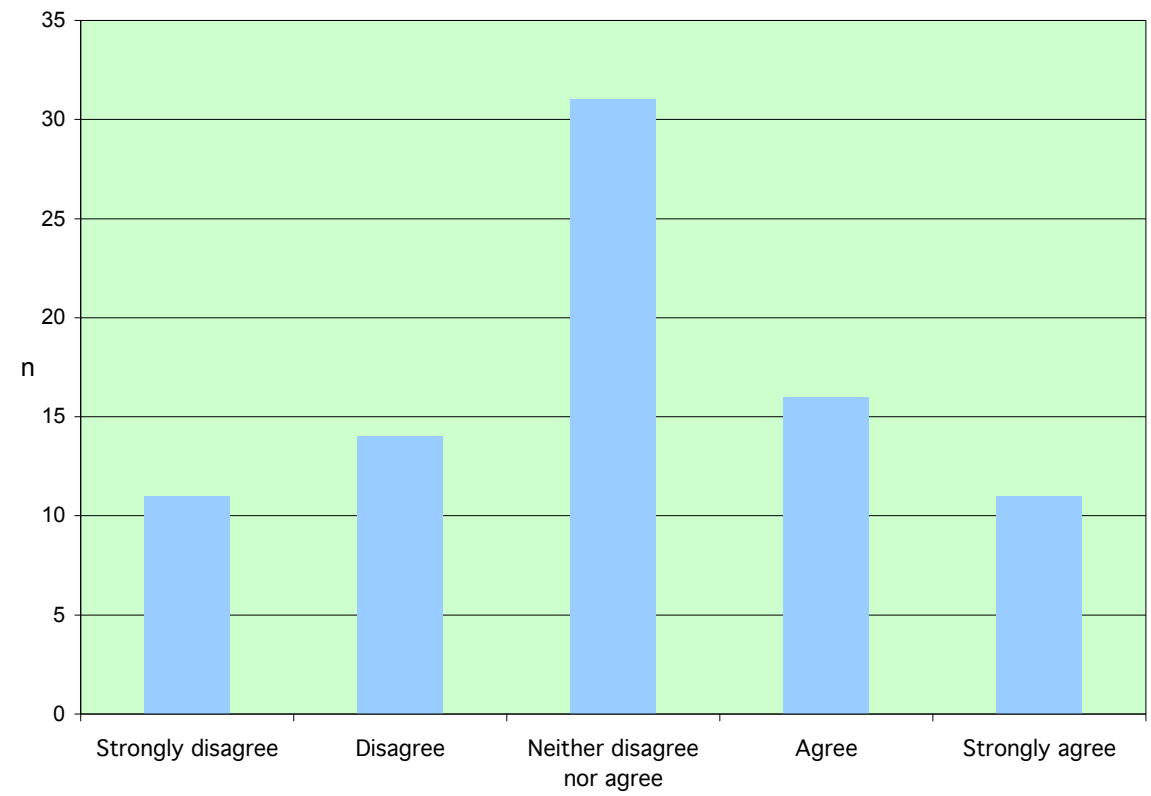

Figure 3: Students' responses to whether they grew to prefer Blackboard Mobile Learn over the personal computer interface 
It is readily apparent that student responses to the questionnaire prompt - I grew to prefer Blackboard Mobile Learn over the personal computer interface - resembled the shape of the normal distribution. The largest proportion of students who responded to this question $(23 \%)$ neither disagreed nor agreed indicating that the app did not make a notable difference to their experience. There was approximate equivalence between those who disagreed $(10 \%)$ and agreed $(12 \%)$ and equivalence between those who strongly disagreed (8\%) and strongly agreed (8\%). The total percentage was $61 \%$, as $39 \%$ of students did not respond to this question.

Beyond the data specifically included to inquire into the relative experience of Blackboard Mobile Learn, two questionnaire items were included to analyse students' reported learning improvement and motivation. Upon returning the iPads, students were asked via a survey question to indicate relative agreement with the statement, the iPad improved my learning. At the same time students were asked to indicate relative agreement with the statement, the iPad motivated me to learn. There were 87 student responses to each of these questions. The results are presented in Figures 4 and 5 below.

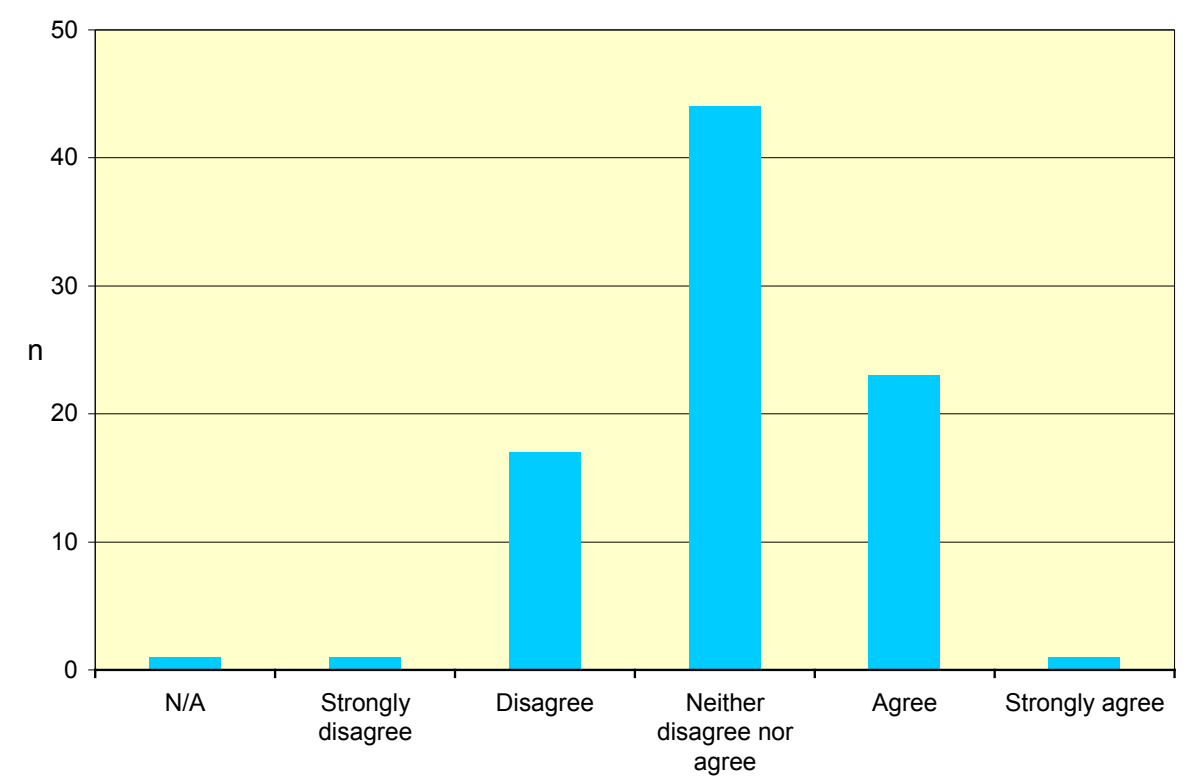

Figure 4: Students' responses to the question, 'The iPad improved my learning'

The largest proportion of responding students (51\%) indicated neither disagreeing nor agreeing that the iPad improved their learning. Of those who indicated a position off the centre mark, there was slightly higher frequency on the side of agreement, with $26 \%$ indicating agreement and 1\% strong agreement, and 20\% disagreement and 1\% strong disagreement. The final percentage point was selection of not applicable.

The distribution of responses to the question, the iPad motivated me to learn, was skewed in that the frequency rose from strongly disagree to the highest response category of agree. The highest frequency of respondents (42\%) indicated agreement, 32\% neither agreeing nor disagreeing, 18\% disagreeing, 3\% strongly disagreeing, 5\% strongly agreeing and no one indicating not applicable. 


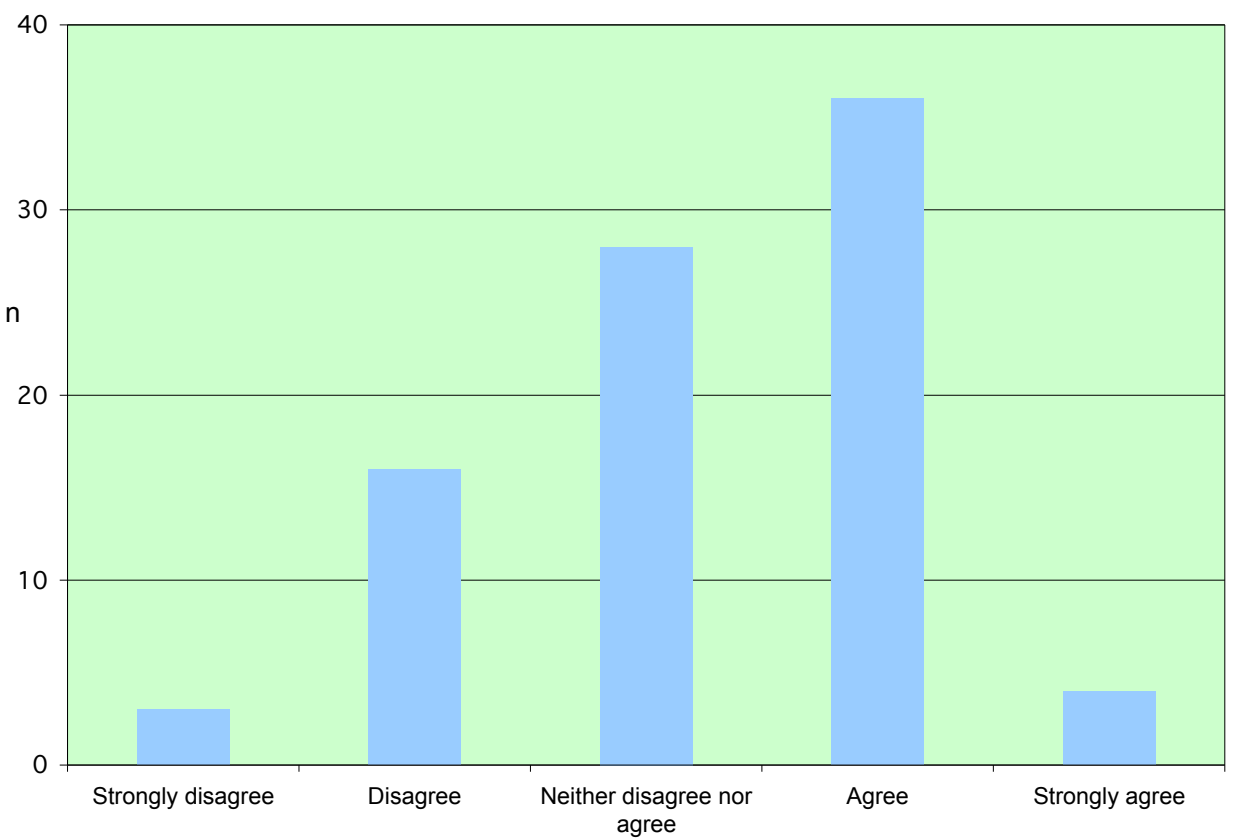

Figure 5: Students' responses to the question, 'The iPad motivated me to learn'

\section{Qualitative data analysis}

Two levels of coding were undertaken for the focus group data. At the first level, general themes were identified and at the second level, these themes were further broken down into sub-themes. The broad pre-identified themes were: student perceptions about mobile learning in general and specific views on Blackboard Mobile Learn.

\section{Perceptions about mobile learning in general}

Students' perceptions of mobile learning varied from finding it 'efficient' to a 'distraction' with more thematic content on positive than negative perceptions. Students opined that mobile learning was efficient as 'it just kind of has it all in one place' and that 'it's easier to be on that all the time' and also 'really, really useful for visual learners'. Students felt that mobile learning would be more effective 'if everyone had all their textbooks on there' which would also make education 'a lot cheaper'.

\section{Views on Blackboard Mobile Learn}

The views on Blackboard Mobile were further divided into the emergent sub-themes of 'accolades' and 'brickbats'.

\section{Accolades}

Immediately following two-week iPad loans, students reported that they had used Blackboard Mobile Learn frequently and extensively. A sample comment was, 'I am constantly checking my iLearn'. Many respondents made comments such as, 'it was 
pretty good all over'. Students reported finding the application easy to use and one student commented 'yeah, I thought that was the best version of the Blackboard there is. It is better than the one on your PC or mobile, it is so much easier to use and it's a much more fun layout too'. The general feedback on Blackboard Mobile Learn was succinctly summarised by a student as 'nice'.

\section{Brickbats}

However, some students indicated ambivalence and/or did not see the need for Blackboard Mobile Learn. Student comments included, 'I didn't really find it that useful', 'it is not something that I walk into class and think yeah I will check that mobile learn' and 'but it's not something I really feel, in fact if I had it on my phone it would be the least used thing in, I would never use it because there is never a time when I am like, I just have to find out what is on iLearn, it can always wait'. Some students did not see how Blackboard Mobile Learn was any different from the version of Blackboard they access from their PCs. A sample comment is, 'I couldn't understand the difference between iLearn and I'm like what, is it the same thing or what'.

Some students identified particular elements of Blackboard Mobile Learn with which they were dissatisfied. For example, one student said:

You really, like you can't save any of the things and they kind of pop up and you want
to have two of them on the screen, I kinda found it useless in that way, that you
couldn't save it and bring it up later, to get back like to the PDF you had to go Login
get to all of it, while you are trying to write notes a little bit.

Some students found it difficult to interact with and slow to load, while some students did not like the layout and found the documents difficult to read. For example, a student said, 'yeah it came up quite small, on the Blackboard Mobile Learn'. One student felt that 'the iPhone version was better than the iPad version' and another commented that the iPad version 'needs a new skin'.

\section{Discussion}

This research revealed key results in regard to mobile learning and associated conditions. With respect to demographics, there was a twelve percentage point difference between use of a computer and self-assessment as 'non-technology users'. In other words, even students who use a computer of some kind all day, every day call themselves 'non-technology users'. There are likewise students who do not consider themselves tech-savvy, even though they were using an Internet-connected device on the day of the survey. Results revealed that in-class, students used their mobile devices for Blackboard Mobile Learn to the same extent as they used them for searching the web for study, accessing university web pages, using email and making Facebook posts, but less than they used them for surfing the web for pleasure and Facebook reading. The majority of students were neutral when asked if they preferred Mobile Learn over PC access to Blackboard. In order to interpret the reported uses and preferences in the wider context of learning, students who loaned iPads loaded with Blackboard Mobile Learn were asked to indicate level of agreement with the statements, the iPad improved my learning and the iPad motivated me to learn. The highest frequency response to learning improvement was neither agree or disagree. On the other hand, the highest frequency response to learning motivation was agree. Qualitative feedback from focus groups was mixed, but largely positive in regard to both mobile learning generally and Blackboard Mobile Learn specifically. 
Phenomenology is an apt methodology with which to analyse this data because it studies people's experiences of everyday life and this is precisely how the students perceived Blackboard Mobile Learn, as ordinary and normal, rather than as phenomenal or extraordinary. Just as the light bulb is a miracle, but flipping a light switch no longer feels miraculous, educational technology is ubiquitous to most 21st century students. A recent post to Facebook reads, "Mobile phone companies should stop advertising their phones on the basis that they can access Facebook because I can access Facebook from my toaster." This joke applies to Blackboard Mobile Learn in that the students' ratings and comments indicate that their experience of it is as primarily a URL or a hook-up. Tapscott (2009) shared a story that his children were embarrassed rather than proud when he was on television for an hour teaching people to surf the Internet. One of his children mockingly asked him, 'What are you going to do next dad, go on TV to teach people how to use the oven?' Those who grew up without them, call tools and devices technology. For most 21st century students, computers are no more technology than eye glasses are to older generations. This explains why even those who use computers all day, every day can still call themselves 'low tech' or even 'nontechnology users'. An apt metaphor to explain this phenomenon is 'a fish doesn't know it is wet' (White \& Gardner, 2011). A differential classification schema also explains why rather than distinctive, the students experienced Blackboard Mobile Learn as neutral. It is a matter of course to the students that they would access their subject site via their mobile devices. A reasonably large proportion of students like using the mobile devices and therefore perceive learning motivation, however, they do not exaggerate or amplify learning outcomes or improvements in that use is ordinary and normative.

Research results indicated that the concept of learning did not emerge as a strong theme in this enquiry into mobile learning. The participating students used the mobile devices more for non-educative purposes than they did to engage in learning. Students were mostly neutral when asked about learning improvement via mobile learning and although slightly more in agreement with perceiving learning motivation, this was still not the majority response. This result regarding low student perception of the learning with mobile devices is replicated elsewhere in the literature. Among the 47 adults responding to Gupta and Koo's (2010) mobile learning survey, only $11 \%$ responded that they use their mobile devices for education. Dyson et al. (2009) wrote, "though mlearning lends itself to a more active approach to education, it does not automatically guarantee that good learning will occur" (p. 263). Considering these results in the context of the largely positive qualitative feedback from students, this research should not be interpreted as rationale for discontinuing mobile learning, but perspective gleaned from the students in that they do not hyperbolise their learning.

\section{Limitations and further research}

The primary limitation of this research was that it was conducted with one group of students at one university. Ethical responsibility to students meant that there could not be a control and an experimental group, thereby preventing experimental design. For this paper, contribution to learning was analysed through student reported experience and perceptions. However, student test scores and other assessment results were collected as part of the larger research project and will be reported in a subsequent paper. One of the intriguing results of this study was the variation between responses to the questions, the iPad improved my learning and the iPad motivated me to learn, in that the highest frequency response to the first question was neither agree or disagree and the 
highest frequency response to the second question was agree. Further research might seek to replicate or challenge this result and further investigate the relationship between perceived learning improvement and motivation.

\section{Conclusion}

The dominant discourse of mobile learning is as revolutionary and/or necessitated by demand of the 21st century student. This research with 135 students, all of whom had access to iPads loaded with the Blackboard Mobile Learn app, over two semesters, presented a challenge to this discourse. The students did not demand mobile learning and were in fact mostly neutral about the experience. Likewise, they did not perceive a notable improvement to their learning. The lesson learned from the relativist perspective of the students should be applied to pedagogical decision-making and instructional design. The students did not oppose mobile learning or Blackboard Mobile Learn, instead accepting it as a natural and yet non-extraordinary part of their university experience. Perhaps educators should not be overly concerned when contemporary students use their mobile devices for in-class purposes other than learning, such as reading Facebook and surfing the net, because it is not categorically different from their now-professors who used their pen and paper to doodle and write letters. Educators are to be encouraged to use mobile learning in their suite of approaches to quality teaching and learning in higher education.

\section{References}

Alvesson, M. \& Sköldberg, K. (2000). Reflexive methodology: New vistas for qualitative research. Thousand Oaks, CA: Sage.

Andone, D., Dron, J. \& Pemberton, L. (2009). Developing a desirable learning environment for digital students. Technology, Instruction, Cognition and Learning, 6(4), 253-271. [verified $27 \mathrm{Apr}$ 2012] http:/ / idt7895.files.wordpress.com/2009/05/ developing-a-desirable-learningenvironment-for-digital-students.pdf

Annetta, L. A. (2008). Video games in education: Why they should be used and how they are being used. Theory into Practice, 47(3), 229-239. http: / / dx.doi.org/10.1080/00405840802153940

Azeem, M., Gondal, M. B., Abida, K., Farah, N., Hussain, A. \& Munira, A. (2009). Defining the standards for higher education. The International Journal of Learning, 16(4), 233-248. http: / / ijl.cgpublisher.com/product/pub.30/prod.2144

Banister, S. (2010). Integrating the iPod Touch in K-12 education: Visions and vices. Computers in the Schools, 27, 121-131. http: / / dx.doi.org/10.1080/07380561003801590

Barrie, S., Ginns, P. \& Prosser, M. (2005). Early impact and outcomes of an institutionally aligned, student focused learning perspective on teaching quality assurance. Assessment $\mathcal{E}$ Evaluation in Higher Education, 30(6), 641-656. http: / / dx.doi.org/10.1080/ 02602930500260761

Biggs, J. \& Tang, C. (2007). Teaching for quality learning at university (3rd ed). Berkshire, England: McGraw-Hill.

Blin, F. \& Munro, M. (2008). Why hasn't technology disrupted academics' teaching practices? Understanding resistance to change through the lens of activity theory. Computers $\mathcal{E}$ Education, 50(2), 475-490. http: / / dx.doi.org/10.1016/j.compedu.2007.09.017

Boyer, E. (1990). Scholarship reconsidered: Priorities of the professoriate. Princeton, NJ: The Carnegie Foundation for the Advancement of Teaching. 
Business Council of Australia (2011). The quality and relevance of higher education will play a major role in determining Australia's economic success: Lifting the quality of teaching and learning in higher education. Melbourne, Victoria: Business Council of Australia. http: / / nla.gov.au/nla.arc-126677

Caverly, D. C., Ward, A. R. \& Caverly, M. J. (2009). Techtalk: Mobile learning and access. Journal of Developmental Education, 33(1), 38-39.

Chalmers, D. (2008). Teaching and learning quality indicators in Australian universities. In The quality, relevance and impact of higher education. Presented at the meeting of the Institutional Management in Higher Education general conference. Paris, France. [verified 27 Apr 2012] http: / / www.oecd.org/ dataoecd/4/40/41216416.pdf

Cobcroft, R. S., Towers, S., Smith, J. \& Bruns, Z. (2006). Mobile learning in review: Opportunities and challenges for learners, teachers, and institutions. In Proceedings Online Learning and Teaching Conference. Brisbane, Queensland: Queensland University of Technology. http: / / eprints.qut.edu.au/5399/1/5399.pdf

Cochrane, T. \& Bateman, R. (2010). Smartphones give you wings: Pedagogical affordances of mobile Web 2.0. Australasian Journal of Educational Technology, 26(1), 1-14. http: / / www.ascilite.org.au/ajet/ajet26/cochrane.html

Colley, A. (2010). iPad sales hit 250,000 in Australia. The Australian, 19 October. http: / / www.theaustralian.com.au / australian-it/ipad-sales-hit-250000-in-australia/ storye6frgakx-1225940397578

Cornelius, S. \& Marston, P. (2009). Towards an understanding of the virtual context in mobile learning. ALT-J: Research in Learning Technology, 17(3), 161-172. http: / / www.researchinlearningtechnology.net/index.php/rlt/article/view / 10874/ 12547

Demirbilek, M. (2010). Investigating attitudes of adult educators towards educational mobile media and games in eight European countries. Journal of Information Technology Education, 9, 235-247. http: / / www.jite.org/ documents/Vol9/JITEv9p235-247Demirbilek777.pdf

Donnison, S. (2009). Discourses in conflict: The relationship between Gen Y pre-service teachers, digital technologies and lifelong learning. Australasian Journal of Educational Technology, 25(3), 336-350. http:/ / www.ascilite.org.au/ajet/ajet25/donnison.html

Dyson, L. E., Litchfield, A., Lawrence, E., Raban, R. \& Leijdekkers, P. (2009). Advancing the mlearning research agenda for active, experiential learning: Four case studies. Australasian Journal of Educational Technology, 25(2), 250-267. http:/ / www.ascilite.org.au/ajet/ajet25/dyson.html

El-Hussein, M. O. M. \& Cronje, J. C. (2010). Defining mobile learning in the higher education landscape. Educational Technology \& Society, 13(3), 12-21. http:/ / www.ifets.info/journals/13_3/3.pdf

Foucault, M. (1972). The archaeology of knowledge. (Tavistock Publications, Ltd., Trans.). London: Routledge. (Original work published 1969)

Gupta, B. \& Koo, Y. (2010). Applications of mobile learning in higher education: An empirical study. International Journal of Information and Communication Technology Education, 6(3), 75-87. http: / / dx.doi.org/10.4018/jicte.2010070107

Guy, R. (Ed.). (2009). The evolution of mobile teaching and learning. Santa Rosa, CA: Informing Science Press.

Hanley, L. (2011). Mashing up the institution: Teacher as bricoleur. Radical Teacher, 90, 9-14. 
Hardy, I. (2010). Academic architectures: Academic perceptions of teaching conditions in an Australian university. Studies in Higher Education, 35(4), 391-404. http: / / dx.doi.org/10.1080/03075070903082334

Huber, M. T. \& Hutchings, P. (2005). The advancement of learning: Building the teaching commons. San Francisco, CA: Jossey-Bass.

Hung, J. \& Zhang, K. (2012). Examining mobile learning trends 2003-2008: A categorical metatrend analysis using text mining techniques. Journal of Computing in Higher Education, 24(1), 117. http: / / dx.doi.org/10.1007/ s12528-011-9044-9

Kazlauskas, A. \& Robinson, K. (2012). Podcasts are not for everyone. British Journal of Educational Technology, 43(2), 321-330. http:/ / dx.doi.org/10.1111/j.1467-8535.2010.01164.x

Kearney, M., Schuck, S., Burden, K. \& Aubusson, P. (2012). Viewing mobile learning from a pedagogical perspective. Research in Learning Technology, 20. http: / / dx.doi.org/10.3402/ rlt.v20i0/14406

Kim, K., Jain, S., Westhoff, G. \& Rezabek, L. (2008). A quantitative exploration of preservice teachers' intent to use computer-based technology. Journal of Instructional Psychology, 35(3), 275-287.

Kinash, S. (2011). New generation of what. Education Technology Solutions, 44, 52-54.

Kinash, S., Mathew, T., Lawson, R., Herbert, J., French, E., Taylor, T., ...Summers, J. (in press). Australian higher education evaluation through assurance of learning. Full paper conference proceedings at the 8th International Conference on Evaluation for Practice, 18-20 June, Pori, Finland. http:/ / www.ucpori.fi/ eval2012

Kukulska-Hulme, A. \& Traxler, J. (Eds.) (2005). Mobile learning. Abingdon, Oxon: Routledge.

Kurubacak, G. (2007). Identifying research priorities and needs in mobile learning technologies for distance education: A Delphi study. International Journal of Teaching and Learning in Higher Education, 19(3), 216-227. http:/ / www.isetl.org/ijtlhe/pdf/IJTLHE178.pdf

Laurillard, D. (2007). Preface. In H. Beetham \& R. Sharpe (Eds.) Rethinking pedagogy for a digital age: Designing and delivering e-learning. London: Routledge.

Mahmoud, S. S. (2008). A proposed model for distributing e-courses content through mobile technology architectures. Proceedings of the World Academy of Science, Engineering and Technology, 27, 274-289. http:/ / mobilelearninghighered.wikispaces.com/ file/view / A+ Proposed+Model+for+Distributing+ECourses.pdf

Martell, K. (2007a). Assessing student learning: Are business schools making the grade? Journal of Education for Business, 82(4), 189-195. http: / / dx.doi.org/10.3200/JOEB.82.4.189-195

Martell, K. (2007b). Interview Kathryn Martell/Interviewer Anjoo Pohkarel: Assurance of learning (AoL) methods just have to be good enough. Journal of Education for Business, 82(4), 241-243. http: / / dx.doi.org/10.3200/ JOEB.82.4.241-243

McKinney, K. (2007). Enhancing learning through the scholarship of teaching and learning: The challenges and joys of juggling. Bolton, MA: Anker.

Middleton, J., Gorard, S., Taylor, C. \& Bannan-Ritland, B. (2008). The “compleat" design experiment: From soup to nuts. In A. E. Kelly, R. A. Lesch \& J. Y. Baek (Eds.), Handbook of design research methods in education: Innovations in science, technology, engineering, and mathematics learning and teaching (pp. 21-46). New York: Routledge.

Mills, S. (1997). Discourse. New York: Routledge. 
Monahan, T. (2007). mCLEV-R: Design and evaluation of an interactive and collaborative mlearning application. International Journal of Emerging Technologies in Learning, 2(2), 47-52. http: / / online-journals.org/i-jet/ article/view/91/61

Park, Y. (2011). A pedagogical framework for mobile learning: Categorizing educational applications of mobile technologies into four types. International Review of Research in Open and Distance Learning, 12(2), 78-102.

http: / / www.irrodl.org/index.php/irrodl/article/view/791/1699

Pope, S. \& Kerris, N. (2010). iPad Wi-Fi + 3G models available in US on April 30. Apple, 20 April http:/ / www.apple.com/pr/library/2010/04/20ipad.html

Proserpio, L. \& Gioia, D. A. (2007). Teaching the virtual generation. Academy of Management Learning E Education, 6(1), 69-80.

Ramsden, P. (2003). Learning to teach in higher education (2nd ed.). London: RoutledgeFalmer.

Rasmussen, C., Stephan, M. (2008). A methodology for documenting collective activity. In A.E. Kelly, R.A. Lesch \& J.Y. Baek, (Eds.), Handbook of design research methods in education: Innovations in science, technology, engineering, and mathematics learning and teaching (pp. 195215), New York: Routledge.

Schepman, A., Rodway, P., Beattie, C. \& Lambert, J. (2012). An observational study of undergraduate students' adoption of (mobile) note-taking software. Computers in Human Behavior, 28(2), 308-317. http:/ / dx.doi.org/10.1016/j.chb.2011.09.014

Sharples, M. (2009). Methods for evaluating mobile learning. In G. Vavoula, N. Pachler \& A. Kukulska-Hulme (Eds.), Researching mobile learning: Frameworks, tools and research designs (2nd ed.) (pp. 17-39). Bern, Switzerland: Peter Lang AG, International Academic Publishers.

Simonson, M. (2010). Millennials - Oh really? Distance Learning, 7(2), 79-80. http:/ / www.highbeam.com/doc/1P3-2277189221.html

Spector, J. M. (2001). An overview of progress and problems in educational technology. Interactive Educational Media, 3, 27-37.

Spradley, J. P. (1979). The ethnographic interview. Fort Worth, TX: Harcourt.

Stiles, R. J., Jones, K. T. \& Paradkar, V. (2011). Analytics rising: IT's role in informing higher education decisions. ECAR Research Bulletin, 7. Boulder, Colorado: EDUCAUSE. [viewed 30 June 2011]. http: / / www.educause.edu/Resources / AnalyticsRisingITsRoleinInform/ 229430

Tapscott, D. (2009). Grown up digital. New York: McGraw Hill.

Traxler, J. (2007). Defining, discussing, and evaluating mobile learning: The moving finger writes and having writ... The International Review of Research in Open and Distance Learning, 8(2), 1-12. http: / / www.irrodl.org/index.php/irrodl/article/view/346/875

Traxler, J. (2009). The evolution of mobile learning. In R. Guy (Ed.). The evolution of mobile teaching and learning (pp 1-14). Santa Rosa, CA: Informing Science Press.

Traxler, J. (2010). Distance education and mobile learning: Catching up, taking stock. Distance Education, 31(2), 129-138. http: / / dx.doi.org/10.1080/01587919.2010.503362

Van Manen, M. (1997). Researching lived experience: Human science for an action sensitive pedagogy. London, Ontario: Althouse.

Vavoula, G., Pachler, N. \& Kukulska-Hulme, A. (Eds.) (2010). Researching mobile learning: Frameworks, tools and research designs (2nd ed.). Bern, Switzerland: Peter Lang AG, International Academic Publishers. 
Wali, E., Winters, N. \& Oliver, M. (2008). Maintaining, changing and crossing contexts: An activity theoretic reinterpretation of mobile learning. ALT-J: Research in Learning Technology, 16(1), 41-57. http:/ / dx.doi.org/10.1080/09687760701850190

Wang, F. \& Hannafin, M. J. (2005). Design-based research and technology-enhanced learning environments. Educational Technology Research and Development, 53(4), 5-23. http: / / dx.doi.org/10.1007/BF02504682

Wang, M., Shen, R., Novak, D. \& Pan, X. (2009). The impact of mobile learning on students' learning behaviours and performance: Report from a large blended classroom. British Journal of Educational Technology, 40(4), 673-695. http: / / dx.doi.org/10.1111/j.1467-8535.2008.00846.x

Wang, R., Wiesemes, R. \& Gibbons, C. (2012). Developing digital fluency through ubiquitous mobile devices: Findings from a small-scale study. Computers $\mathcal{E}$ Education, 58(1), 570-578. http: / / dx.doi.org/10.1016/j.compedu.2011.04.013

White, J. \& Gardner, J. (2012). The classroom $x$-factor: The power of body language and nonverbal communication in teaching. Abingdon, Oxon: Routledge.

Wu, W., Wu, Y. J., Chen, C., Kao, H., Lin, C. \& Huang S. (2012). Review of trends from mobile learning studies: A meta-analysis. Computers \& Education, 59(2), 817-827. http:/ / dx.doi.org/10.1016/j.compedu.2012.03.016

Zawacki-Richter, O., Brown, T. \& Delport, R. (2009). Mobile learning: From single project status into the mainstream? European Journal of Open, Distance and E-Learning. http: / / www.eurodl.org/ materials / contrib / 2009/Richter_Brown_Delport.pdf

\title{
Appendix: iPad Experience Questionnaire
}

Obtain from URL http:/ / www.ascilite.org.au / ajet/ajet28/ kinash-appendix.pdf

\author{
Authors: Dr Shelley Kinash, Associate Professor Higher Education and \\ Director, Office of Quality, Teaching and Learning \\ Bond University QLD 4229. Email: skinash@bond.edu.au \\ Web: http: / / apps.bond.edu.au/staff/profile.asp?s_id=1583 \\ Dr Jeffrey Brand, Associate Professor \\ Faculty of Humanities and Social Sciences \\ Bond University QLD 4229. Email: jbrand@bond.edu.au \\ Web: http: / / apps.bond.edu.au/staff / profile.asp?s_id=117 \\ Trishita Mathew, Senior Research Assistant \\ Faculty of Humanities and Social Sciences \\ Bond University QLD 4229. Email: trmathew@bond.edu.au \\ Web: http: / / apps.bond.edu.au/staff/profile.asp?s_id=828
}

Please cite as: Kinash, S., Brand, J. \& Mathew, T. (2012). Challenging mobile learning discourse through research: Student perceptions of Blackboard Mobile Learn and iPads. Australasian Journal of Educational Technology, 28(4), 639-655.

http: / / www.ascilite.org.au/ajet/ajet28/kinash.html 